\title{
Chemical Composition Similarity between the Essential Oils Isolated from Male and Female Specimens of Each Five Baccharis Species
}

\author{
Michele A. Besten, ${ }^{a}$ Vanessa C. G. Jasinski, ${ }^{a}$ Ângela de G. L. C. Costa, ${ }^{a}$ Domingos S. Nunes, ${ }^{* a}$ \\ Sávio L. Sens, ${ }^{b}$ Alberto Wisniewski Jr., ${ }^{c}$ Edesio L. Simionatto, ${ }^{d}$ Dilamara Riva, ${ }^{d}$ \\ Juliana B. Dalmarco ${ }^{d}$ and Daniel Granato ${ }^{e}$
}

${ }^{a}$ Departamento de Química, Universidade Estadual de Ponta Grossa, 84030-900 Ponta Grossa-PR, Brazil

${ }^{b}$ Centro de Educação Tecnológica Irmão Mário Cristóvão (TECPUC), 80215-901 Curitiba-PR, Brazil

'Departamento de Química, Universidade Federal de Sergipe, 49100-000 São Cristóvão-SE, Brazil

${ }^{d}$ Laboratório de Cromatografia, Fundação Universidade Regional de Blumenau, 89030-000 Blumenau-SC, Brazil

eInstituto Adolfo Lutz, Centro de Materiais de Referência, Av. Dr. Arnaldo, 355, 01246-000 São Paulo-SP, Brazil

\begin{abstract}
Nos poucos estudos publicados comparando óleos essenciais de espécimes femininos e masculinos de espécies Baccharis, fortes diferenças entre as composições de ambas as amostras foram sempre encontradas. Os experimentos realizados nesta pesquisa utilizam estratégias para minimizar a interferência de fatores genéticos e ecológicos. Os óleos essenciais das folhas de espécimes femininos e masculinos de cinco espécies Baccharis foram pesquisados com uso de um cromatógrafo gasoso acoplado a um espectrômetro de massas e a um detector de ionização de chama (CG-EM-DIC): B. caprariaefolia e B. dracunculifolia, já pesquisadas anteriormente com objetivos similares; e B. coridifolia, B. semiserrata var. elaegnoides e B. pentaptera, as duas últimas ainda não mencionadas na literatura química. Os resultados foram acompanhados por análise hierárquica de grupos, verificando-se a formação de grupos indicativos da grande similaridade entre óleos essenciais dos espécimes masculinos e femininos de todas as cinco espécies. O estudo reafirma o valor das observações de campo na pesquisa de produtos naturais, e aponta fatores genéticos e ecológicos como principais responsáveis por diferenças no metabolismo secundário das plantas estudadas.
\end{abstract}

In the few studies published on essential oils from female and male specimens of Baccharis species, strong differences between the compositions of both samples were always found. The experiments conducted in this study make use of strategies to minimize the interference from genetic and environmental factors. Essential oils from leaves of female and male specimens of five Baccharis species were investigated by gas chromatography-mass spectrometry plus flame ionization detector (GC-MS-FID): B. caprariaefolia and B. dracunculifolia, which have been previously studied with similar aims; and $B$. coridifolia, $B$. semiserrata var. elaegnoides and $B$. pentaptera, the latter two not yet mentioned in the literature. The results were followed by hierarchical cluster analysis, verifying the formation of groups indicative of the great similarity of essential oils from male and female specimens of all five species. The study reinforces the value of field observation in natural product research and points genetic and ecological factors as main responsible for differences in the secondary metabolites of the studied plants.

Keywords: Baccharis species, male and female specimens, essential oils

*e-mail: dsnunes@pq.cnpq.br 


\section{Introduction}

Review articles show that the research regarding the chemical compounds produced by about 120 species from the Baccharis L. (Asteraceae) genus resulted mainly in the isolation of diterpenes and flavonoids. ${ }^{1,2}$ On the other hand, the available data show that about 52 species from the Baccharis genus have been characterized on the basis of the chemical composition of their essential oils. The seasonal variability of the chemical composition of essential oils from some Baccharis species cultivated or growing in natura has already been reported, and it is widely accepted that ecological and geographical factors, such as luminosity, ${ }^{3}$ rainfall regimes, ${ }^{4}$ mineral content in the soil, ${ }^{5}$ interaction with insects and predators, ${ }^{6}$ and location and altitude, ${ }^{7}$ exert influence on the content of volatile metabolites in plants of this genus. In addition, the extraction method used to obtain the essential oil may affect its chemical composition. ${ }^{8}$

The number of Baccharis species whose essential oils have already been studied is very small considering that this botanical genus contains between 360 and 500 species. ${ }^{9} 10$ Most published articles refer to collections made in Brazil, especially in the South region. On the other hand, the essential oils from a reduced group of 8 species, which were collected in at least three different locations, were better studied: B. articulata (Lam.) Pers., ${ }^{11-15}$ B. crispa Spreng., ${ }^{12,16,17}$ B. dracunculifolia DC., ${ }^{4,7,18-20}$ B. genistelloides (Lam.) Pers., ${ }^{21-23}$ B. latifolia Pers., ${ }^{19,24,25}$ B. salicifolia (Ruiz et Pav.) Pers., ${ }^{17,19,24,26,27}$ B. trimera, ${ }^{5,16,28,29}$ and B. uncinella. ${ }^{7,14,30-33}$

Taking into consideration all information available in the literature, it becomes evident that more studies need to be performed on the chemical composition of essential oils extracted from the Baccharis species, which are recognized by their intense environmental relation with a diverse number of animals, especially insects. ${ }^{34,35}$ Geographical and environmental factors have a strong influence on the composition of essential oils of $B$. dracunculifolia and $B$. uncinella DC. as shown by collecting these plants in different places and altitudes. ${ }^{7,30,31}$

In a few number of studies that regard essential oils, authors have assumed that Baccharis species are dioecious, which means that there may be significant differences on the secondary metabolism of male and female specimens from the same species. As a matter of fact, significant differences on the volatile secondary metabolites of male and female specimens were found in B. caprariaefolia DC., B. dracunculifolia and B. erioclada DC., ${ }^{4}$ B. articulata (Lam.) Pers., ${ }^{11}$ B. trimera (Less.) DC., ${ }^{28}$ and B. semiserrata DC. ${ }^{36}$
Based on these considerations, we aim to present the results of the GC-MS-FID (gas chromatography-mass spectrometry plus flame ionization detector (GC-MS-FID)) analysis of essential oils obtained from the leaves of five Baccharis species that grow in natura in the Second Plateau of Paraná (Paraná State, Brazil). Although the fact that the essential oils from male and female specimens of B. caprariaefolia and B. dracunculifolia had already been studied before, ${ }^{4}$ the oils obtained from $B$. coridifolia DC., B. semiserrata var. elaegnoides (Steud. ex Baker) G. M. Barroso and B. pentaptera (Less.) DC. were compared in relation to their chemical composition and the results are presented for the first time in the literature. The results presented and discussed here may help to a better understanding about the main factors that may cause differences in the chemical composition of essential oils obtained from male and female specimens of Baccharis species.

\section{Experimental}

\section{Collection of plant material}

The plants were collected on private lands along the PR513 Highway, Ponta Grossa City, Paraná State, Brazil (900 to $1070 \mathrm{~m}$ of altitude), in places up to $3 \mathrm{~km}$ far from the point $25^{\circ} 07^{\prime} \mathrm{S}$ and $50^{\circ} 00^{\prime} \mathrm{W}$. Voucher herbarium specimens have been deposited at Museu Botânico Municipal de Curitiba (Paraná State, Brazil) under the following numbers (female/male): B. caprariaefolia DC. (338988/338981, collected on September 17, 2007, at 4 p.m.), B. semiserrata DC. var. elaegnoides (Steud.) G. M. Barroso (338984/338989, September 14, 2007, at 5 p.m.), B. coridifolia DC. (931131/931130, April 20, 2007, at 4 p.m.) and B. pentaptera (Less.) DC. (338985/338987, February 12, 2009, at 11 a.m., in the shade of high Eucalyptus trees. The female/male specimens of B. dracunculifolia DC. (338982/338991) were the only ones that have been collected off-flowering season: the plants were marked using plastic tags in March, during the flowering season, and then collected on August 8, 2006, at 2 p.m.

\section{Extraction of the essential oils}

The plant materials were dried at room temperature for 2-4 days, carefully hand-selected to separate the leaves, which were kept in a closed amber container, protected from light, at $-18^{\circ} \mathrm{C}$. At the day of the extraction, the leaves were chopped using a multi-processor, and the essential oils were obtained by hydrodistillation in a glass apparatus 
using 80-100 g of each plant material and 0.8-1.0 L of distilled water, for $2.5 \mathrm{~h} .{ }^{37}$ The oils were separated with ethyl ether and the organic phase was dried using anhydrous $\mathrm{Na}_{2} \mathrm{SO}_{4}$. The solutions were filtered and the solvent was evaporated under vacuum and at a low temperature.

\section{Essential oil analysis}

The essential oils were analyzed by a Varian ${ }^{\circledR}$ CP-3800 gas chromatograph using the software Saturn ${ }^{\circledR}$ GC-MS workstation 5.51, operating at EI mode at $70 \mathrm{eV}$, with a mass scan range of 40-650 m/z at a sample rate of $1.0 \mathrm{scan} \mathrm{s}^{-1}$. A capillary column CP-Sil-8 CB Low Bleed/MS $30 \mathrm{~m}$ long was used, with a diameter of $0.25 \mathrm{~mm}$ and a film of $0.25 \mu \mathrm{m}$. The temperature of the injector was kept at $250{ }^{\circ} \mathrm{C}$ and the temperature of the interface at $240{ }^{\circ} \mathrm{C}$. A flow rate of $5 \mathrm{~mL} \mathrm{~min}^{-1}$ was adopted, and helium was the carrier gas. The injection volume was $1.0 \mu \mathrm{L}$ of oil (diluted in ethyl ether). The temperature was programmed to increase in accordance with the following conditions: $50^{\circ} \mathrm{C}$ in the first minute, then going up $3{ }^{\circ} \mathrm{C} \min ^{-1}$ up to $240{ }^{\circ} \mathrm{C}$, and split ratio of $1 / 50$. The relative retention indices were calculated by using the data of the injection of a series of n-alkanes (C10-C30) in the same chromatographic conditions as those used for the oil. ${ }^{38}$ Isolated standards of heptanal, $\alpha$-pinene, limonene, linalool, caryophyllene, viridiflorol, guaiacol, camphor, trans-anetol, safrol, thymol, eugenol and tertbutil-hydroxytoluene were used to validate the system and guarantee the reliability of the calculated indices.

In order to quantify the chemical compounds in each oil sample, a Shimadzu gas chromatograph 14B with a flame ionization detector (GC-FID) and an OV-5 column $(30 \mathrm{~m} \times 0.25 \mathrm{~mm}$ d.i. $\times 0.25 \mu \mathrm{m})$ was used. Nitrogen was used as gas carrier with a constant pressure of $80 \mathrm{kPa}$, a split ratio of 1/150 and injection volume of oil (diluted in ethyl ether) of $1 \mu \mathrm{L}$. The temperatures of the detector and the injector were kept at 300 and $250^{\circ} \mathrm{C}$, respectively. The initial temperature in the column was $50{ }^{\circ} \mathrm{C}$ (for $3 \mathrm{~min}$ ), with a heating rate of $5{ }^{\circ} \mathrm{C} \mathrm{min}^{-1}$ until the temperature reached $2700^{\circ} \mathrm{C}$, with an isotherm of $8 \mathrm{~min}$. Results are presented (Table 1) in terms of the relative composition of each sample.

\section{Statistical analysis}

Data were processed using hierarchical cluster analysis (HCA) to simultaneously analyze associations among all results and to highlight the chemical similarity among the specimens. HCA was applied to the auto-scaled data using a one-step approach: the Ward's method as the amalgamation rule and Euclidean distances as metric were used to generate a dendrogram for samples. ${ }^{39}$ In order to verify statistical differences between male and female specimens in relation to the total concentration of monoterpenes, sesquiterpenes, oxygenated monoterpenes, oxygenated sesquiterpenes, yield of essential oil and the monoterpene/sesquiterpene ratio, the $\chi^{2}$ test was used. A $p$-value below $5 \%$ was considered to be significant. The software Statistica v.7.1 (Statsoft, Tulsa, OK, USA) was used for all statistical analyses.

\section{Results and Discussion}

The results of the GC-MS-FID analyses of the essential oils obtained from the leaves of male and female specimens of five Baccharis species are presented in Table 1. The relative compositions of the samples are presented in a crescent order of RI (mean of calculated relative retention indices) components, which were measured in apolar columns (CP-Sil-8 CB and OV-5) and compared with the data published by Adams for a DB- 5 column. ${ }^{40}$

The marked differences usually found in the composition of essential oils from male and female specimens of Baccharis species, as well outlined in the literature, have not yet been fully explained. ${ }^{4,11,28,36}$ In the present research, since the plant materials from male and female specimens of five Baccharis species were collected at the same time and place, and then prepared, extracted and analyzed using the same experimental methods and conditions, the results shown in Table 1 are harmonious, in a general way. The male and female specimens from each species presented very similar yields. In general, all samples presented a low ratio of monoterpene to sesquiterpene, and this characteristic has also been observed in essential oils extracted from the leaves of other Baccharis species collected in the same geographical region in different seasons. ${ }^{33,36}$

The results of male and female specimens were statistically similar $(p>0.05)$ only for some of the main chemical components and for the monoterpene/ sesquiterpene ratios (Table 1). The monoterpene/ sesquiterpene ratio and total content of monoterpenes were significantly different $(p<0.05)$ for $B$. dracunculifolia, $B$. semiserrata var. elaegnoides, and $B$. pentaptera.

The essential oils of $B$. caprariaefolia, which belongs to the Discolores section of the Baccharis genus, presented a very peculiar composition (Table 1) when compared with results published elsewhere. ${ }^{4}$ With the results obtained in this research, the essential oils from this species were characterized by the low content of monoterpenes and four main sesquiterpenes ( $\beta$-caryophyllene, germacrene $D$, $\alpha$-selinene and spathulenol), totalling more than $60 \%$ of the relative composition in both male and female specimens. 


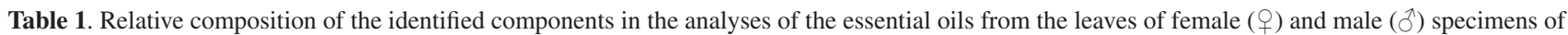
B. caprariaefolia (Bca), B. dracunculifolia (Bdr), B. semiserrata var. elaegnoides (Bse), B. coridifolia (Bco) and B. pentaptera (Bpe) belonging to several sections* of the Baccharis genus

\begin{tabular}{|c|c|c|c|c|c|c|c|c|c|c|c|c|}
\hline \multirow{2}{*}{ Components } & \multirow{2}{*}{$\mathrm{RI}^{\mathrm{a}}$} & \multirow{2}{*}{$\mathrm{RI}^{\mathrm{b}}$} & \multicolumn{4}{|c|}{ Discolores* } & \multicolumn{2}{|c|}{ Nitidae* $^{*}$} & \multicolumn{2}{|c|}{ Paniculatae $^{*}$} & \multicolumn{2}{|c|}{ Caulopterae $^{*}$} \\
\hline & & & $\mathrm{Bca}+$ & $\mathrm{Bca}_{\triangle}^{\pi}$ & $\mathrm{Bdr}+$ & $\operatorname{Bdr} \widehat{\jmath}$ & Bse욱 & $\mathrm{Bse}^{\pi}$ & $\mathrm{Bco}+$ & $\mathrm{B} \cos$ & Bpe + & $\mathrm{Bpe}^{\pi}$ \\
\hline$\beta$-Pinene & 977 & 980 & 0.32 & 0.31 & 0.10 & 1.58 & nd & nd & 0.11 & 0.12 & 1.05 & nd \\
\hline Limonene & 1029 & 1031 & 0.21 & 0.22 & 0.45 & 0.43 & 1.23 & 3.07 & 1.46 & 1.20 & 0.95 & 0.10 \\
\hline Linalool & 1101 & 1098 & nd & nd & nd & nd & 0.24 & 0.22 & nd & nd & 0.56 & 1.20 \\
\hline Terpinen-4-ol & 1180 & 1177 & nd & nd & 0.40 & 0.34 & nd & nd & 0.22 & 0.20 & nd & nd \\
\hline$\delta$-Elemene & 1339 & 1339 & 1.35 & 1.42 & nd & nd & nd & nd & nd & nd & nd & nd \\
\hline$\alpha$-Cubebene & 1350 & 1351 & nd & nd & 0.65 & 0.43 & nd & nd & 0.34 & 0.55 & nd & nd \\
\hline$\beta$-Elemene & 1375 & 1375 & 2.19 & 1.49 & 0.93 & 0.72 & 0.65 & 0.44 & 0.22 & 0.33 & nd & nd \\
\hline$\alpha$-Copaene & 1376 & 1376 & nd & nd & 0.67 & 0.99 & 0.46 & 0.34 & nd & nd & 1.13 & 0,10 \\
\hline$\alpha$-Gurjunene & 1410 & 1409 & nd & nd & 0.46 & 0.63 & nd & nd & nd & nd & nd & nd \\
\hline$\beta$-Caryophyllene & 1419 & 1418 & 13.38 & 15.75 & 7.88 & 8.88 & 2.62 & 3.65 & 3.53 & 4.86 & 2.31 & 3.78 \\
\hline Aromadendrene & 1440 & 1439 & nd & nd & 2.93 & 3.02 & 0.12 & 0.21 & nd & nd & 1.18 & 1.81 \\
\hline$\beta$-Humulene & 1442 & 1440 & 2.01 & 1.48 & 4.61 & 2.18 & nd & nd & nd & nd & nd & nd \\
\hline$\gamma$-Muurolene & 1478 & 1477 & nd & nd & 3.48 & 2.33 & 0.26 & 0.34 & nd & nd & 0.99 & 0.10 \\
\hline Germacrene D & 1481 & 1480 & 14.01 & 9.75 & 5.53 & 4.04 & nd & nd & 0.62 & 0.91 & nd & 1.44 \\
\hline$\beta$-Guaiene & 1491 & 1490 & nd & nd & 7.98 & 6.06 & 0.18 & 0.22 & nd & nd & nd & nd \\
\hline Viridiflorene & 1494 & 1493 & 0.11 & 0.13 & nd & nd & 0.44 & 0.36 & 0.66 & 0.65 & nd & 1.04 \\
\hline$\alpha$-Selinene & 1497 & 1494 & 14.44 & 14.81 & nd & nd & 0.33 & 0.15 & 0.42 & 0.38 & 0.94 & nd \\
\hline$\gamma$-Cadinene & 1511 & 1513 & nd & nd & 2.22 & 2.50 & nd & nd & nd & nd & 0.56 & 0.95 \\
\hline$\delta$-Cadinene & 1522 & 1524 & 1.59 & 1.55 & 7.34 & 5.48 & 2.19 & 2.04 & 0.88 & 0.74 & 2.52 & 1.30 \\
\hline (E)-Nerolidol & 1566 & 1564 & 0.61 & 0.73 & 24.69 & 17.16 & 1.77 & 2.36 & nd & nd & nd & nd \\
\hline Spathulenol & 1578 & 1576 & 22.69 & 23.02 & 14.62 & 21.39 & 30.74 & 35.37 & 34.35 & 36.57 & 43.68 & 48.47 \\
\hline Caryophyllene oxide & 1583 & 1581 & 5.73 & 9.65 & 1.16 & 2.07 & 19.39 & 23.32 & 16.83 & 14.92 & 9.21 & 18.66 \\
\hline Viridiflorol & 1591 & 1590 & 0.44 & 0.10 & 1.61 & 0.88 & 5.03 & 4.16 & 5.75 & 5.07 & 3.57 & 2.81 \\
\hline Carotol & 1596 & 1594 & 1.48 & 1.27 & 1.03 & 1.57 & 5.22 & 2.82 & 4.43 & 6.01 & nd & nd \\
\hline$\alpha$-Cadinol & 1652 & 1653 & 2.42 & 2.73 & 1.90 & 2.83 & 4.42 & 2.49 & 1.39 & 1.21 & 7.60 & 2.10 \\
\hline Patchouli alcohol & 1656 & 1659 & 0.88 & 0.10 & 0.10 & 1.34 & 2.47 & 1.40 & 4.25 & 3.84 & nd & nd \\
\hline$\beta$-Bisabolol & 1665 & 1668 & 0.53 & 0.71 & 0.84 & 2.86 & 1.33 & 0.94 & 2.43 & 2.22 & nd & nd \\
\hline$\alpha$-Bisabolol & 1679 & 1683 & 1.89 & 0.10 & 1.86 & 0.10 & nd & nd & 4.62 & 5.01 & nd & nd \\
\hline \multicolumn{3}{|l|}{ Total identified / \% } & 86.28 & 85.32 & 93.82 & 90.39 & 78.09 & 83.90 & 82.51 & 84.79 & 76.25 & 83.86 \\
\hline \multicolumn{3}{|c|}{ Monoterpenes hydrocarbons / \% } & 0.53 & 0.53 & $0.95 * *$ & $2.35 * *$ & $0.47 * *$ & $3.29 * *$ & 1.79 & 1.52 & $2.56 * *$ & $1.30 * *$ \\
\hline \multicolumn{3}{|c|}{ Oxygenated monoterpenes / \% } & 0.00 & 0.00 & 0.40 & 0.34 & 0.24 & 0.22 & 0.22 & 0.20 & $0.56^{* *}$ & $1.20 * *$ \\
\hline \multicolumn{3}{|c|}{ Sesquiterpenes hydrocarbons / \% } & 85.75 & 84.79 & 92.87 & 88.04 & 77.62 & 80.61 & 80.72 & 83.27 & 73.69 & 82.56 \\
\hline \multicolumn{3}{|c|}{ Oxygenated sesquiterpenes / \% } & 36.67 & 38.41 & 47.81 & 50.20 & 70.37 & 72.86 & 74.05 & 74.85 & 64.06 & 72.04 \\
\hline \multicolumn{3}{|c|}{ Monoterpene/Sesquiterpene ratio } & 0.006 & 0.006 & $0.010^{* *}$ & $0.026^{* *}$ & $0.006^{* *}$ & $0.041 * *$ & 0.022 & 0.018 & $0.035^{* *}$ & $0.016^{* * *}$ \\
\hline \multicolumn{3}{|c|}{ Sample yielding $(\mathrm{m} / \mathrm{m}) / \%$} & 0.32 & 0.34 & 0.81 & 0.85 & 0.25 & 0.23 & 0.54 & 0.54 & 0.18 & 0.17 \\
\hline
\end{tabular}

RI': means of calculated relative retention indices using the apolar columns CP-Sil-8 (GC-MS) and OV-5 (GC-FID) and the n-alkane series C10-C30; $\mathrm{RI}^{\mathrm{b}}$ : published retention indices for the apolar column DB-5;40 nd: not detected or $<0.10 \%$; the symbol ** in the same line, for the same Baccharis species, represent statistical different results according to $\chi^{2}$ test.

The second Discolores of the group of five species analyzed (B. dracunculifolia) also presented essential oils with a low content of monoterpenes, which contributed to the statistical difference $(p<0.05)$ in the monoterpene/ sesquiterpene ratio between male (0.026) and female $(0.010)$ specimens. This difference was due to a higher concentration of $\beta$-pinene present in the essential oil of the male specimen. The main sesquiterpenes present in this 
species were also earlier identified as principal components in oils obtained from botanical materials collected in several places, and their content. Exception must be made to trans- $\beta$-guaiene, that was found here for the first time as a main component (7.9-6.1\%) in essential oils from this species. . $7,18,19,31,32,41,42^{2}$

Baccharis dracunculifolia blossoms between January and April, a period of intense rainfall in the region where the plant material has been collected. However, the year of 2006 was one of the driest years in that region, with rainfall precipitations below the monthly average of six years before, and the plant material was collected on a sunny afternoon, after several days without rain, at the end of the drought period. The low monoterpene/ sesquiterpene ratios and the high yield of essential oils from both specimens are in accordance with those found by Ferracini et al. ${ }^{4}$ The botanical samples of all five Baccharis species analyzed in this research were collected during dry periods, especially for B. dracunculifolia allowing to compare the results with published data on this species. ${ }^{4}$ The experiments with this plant were designed to verify the similarity between the oils of male and female specimens under low water availability at the time of collection. It is noteworthy that, at least regarding the compositions of the essential oils, the metabolisms of male and female specimens seem to be similar outside the flowering period. The climatic conditions adopted as standard for the experiments in this research decrease the possible effects of water availability on the metabolism of the plants and minimize the pressure of this variable in the statistical analysis. Nevertheless, it seems to be commonly accepted that the water availability for a plant, or even the water stress that the plant is submitted to, can be adequately measured by a Scholander pressure chamber, ${ }^{43}$ that could be used with advantages in the research about effects of such factors on the volatile composition of Baccharis species. ${ }^{44,45}$

The other three species analyzed in this study belong to three different sections of the genus: Nitidae (B. semiserrata var. elaegnoides), Paniculatae (B. coridifolia) and Caulopterae (B. pentaptera).$^{9,46,47}$ The essential oils extracted from all three species had a similar profile by presenting low monoterpene/sesquiterpene ratios and co-occurrence of many major compounds, principally the sesquiterpene spathulenol and caryophyllene oxide. A very different composition of an essential oil from the aerial parts of flowering female $B$. coridifolia has been published, ${ }^{48}$ whereas no studies could be found on the volatiles from $B$. semiserrata var. elaegnoides and B. pentaptera. The data in Table 1 show no relation between chemical compositions of samples and the Baccharis sections or vice-versa.
However, in a study performed by Zunino et al. ${ }^{17}$ the authors assessed the chemical composition of essential oils from eight Baccharis species belonging to the Caulopterae section, and verified that carquejyl acetate was the only compound present in high concentrations in one species, and was therefore considered the chemical marker for B. trimera grown in natura in Southern Brazil, Uruguay and many regions of Argentina. ${ }^{17}$ The published data and those presented here show that the essential oils from Baccharis rarely contain useful chemical markers from the chemotaxonomical standpoint.

By analyzing the data in Table 1, it is somewhat difficult to verify differences/associations among samples for all chemical compounds assessed in the essential oils and, therefore, a multivariate statistical approach was adopted to address this limitation. Using HCA applied to the samples (Figure 1), four clusters were suggested:

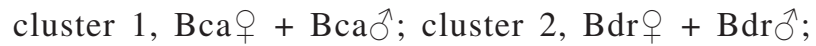
cluster $3, \mathrm{~B} \operatorname{co}{ }^{\lambda}+\mathrm{B} \operatorname{co} \varphi+\mathrm{Bse}{ }^{\lambda}+\mathrm{Bse} \varphi$; and

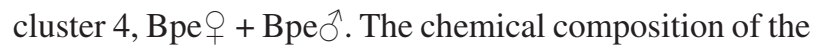
oils from the male and female specimens of Bse and Bco is very similar, as they were grouped in the same cluster. Likewise, the chemical composition of the essential oils

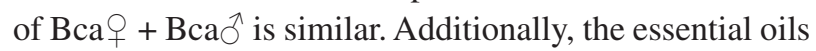
present in cluster $2 /$ cluster 4 are also very similar.

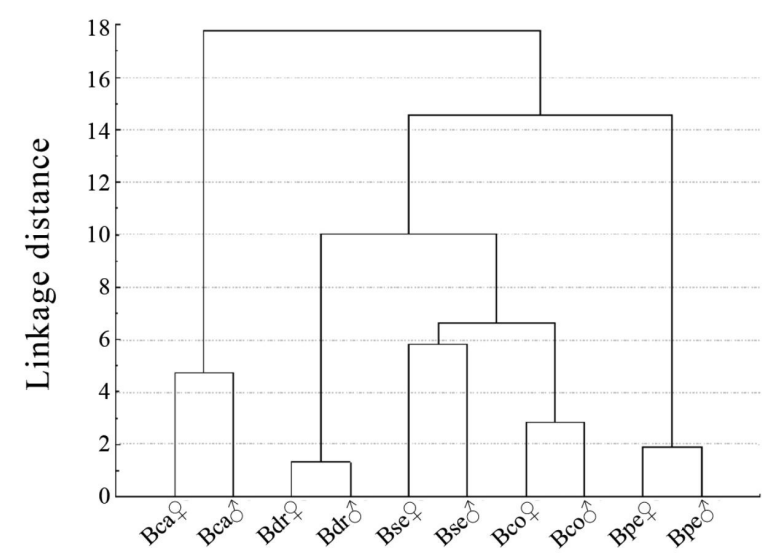

Figure 1. Cluster analysis applied for the samples using all 28 identified volatile compounds presented in the Table 1 as variables.

Therefore, it is possible to conclude that the chemical composition of male and female specimens within the same Baccharis species is quite similar, and the statistical approach used in this study was adequate to classify the samples in relation to the chemical composition of the essential oils. It is known that HCA groups objects based only on the response variables to characterize and describe the essential oils. The goal of HCA application is that the essential oils within the same cluster be similar (or related) to one another and different from the oils in other clusters. 
The greater the similarity within a group and the greater the difference between groups, better will be the clustering. It is noteworthy that the Ward's method uses an analysis of variance approach to evaluate the distances between clusters, minimizing the sum of squares of clusters and this fact creates clusters of small sizes because the more the observations are scattered, the sum of squares makes the distance bigger. ${ }^{39}$

\section{Conclusions}

With regard to the chemical composition of the essential oils from male and female specimens of five different Baccharis species, the results show clear similarities between the metabolism of male and female specimens, both during and outside of the flowering period. The chemical composition of the essential oils from male and female specimens of $B$. semiserrata var. elaegnoides and $B$. pentaptera were presented here for the first time in the literature. The essential oils of all five species studied in this research show low levels of monoterpenes, similar to the oils from two other Baccharis species previously collected in the same region. The question on the low ratio monoterpene/sesquiterpene found in oils of Baccharis species growing in natura in the Second Plateau of Paraná points to the need for further research. The use of hierarchical cluster analysis allowed the identification of a high similarity in the chemical composition between male and female specimens of five different Baccharis species. No association between the chemical composition of the essential oils and the sections of the Baccharis genus was observed.

\section{Supplementary Information}

Supplementary material (Tables S1, S2 and S3 and Figure S1) is available free of charge at http://jbcs.sbq.org.br as a PDF file.

\section{Acknowledgments}

We thank Coordenação de Aperfeiçoamento de Pessoal de Nível Superior (CAPES) for the financial support used to develop three Master in Science projects (M. A. Besten, V. C. G. Jasinski, A. G. L. C. Costa) and for one Master in Science scholarship (M. A. Besten), Conselho Nacional de Desenvolvimento Científico e Tecnológico (CNPq) (478229/2006-2), Fundação Araucária (047/2007-1573) for the financial support, and Dr. Gerth Hatschbach for his great effort on the botanical identification.

\section{References}

1. Verdi, L. G.; Brighente, I. M. C.; Pizzolatti, M. G.; Quim. Nova 2005, 28, 85 .

2. Abad, M. J.; Bermejo, P.; ARKIVOC 2007, VII, 76.

3. Silva, F. G.; Pinto, J. E. B. P.; Cardoso, M. G.; Nascimento, E. A.; Nelson, D. L.; Sales, J. F.; Mol, D. J. S.; Ciênc. Agrotec. 2006, 30, 52 .

4. Ferracini, V. L.; Paraíba, L. C.; Leitão-Filho, H. F.; Da Silva, A. G.; Nascimento, L. R.; Marsaioli, A. J.; J. Essent. Oil Res. 1995, 7, 355 .

5. Silva, F. G.; Oliveira, C. B. A.; Pinto, J. E. B. P.; Nascimento, V. E.; Santos, S. C.; Seraphin, J. C.; Ferri, P. H.; J. Braz. Chem. Soc. 2007, 18, 990.

6. Damasceno, F. C.; Nicoli, K. P.; Caramão, E. B.; Soares, G. L. G.; Zini, C. A.; J. Braz. Chem. Soc. 2010, 21, 556.

7. Frizzo, C. D.; Atti-Serafini, L.; Laguna, S. E.; Cassel, E.; Lorenzo, D.; Dellacassa, E.; Flav. Fragr. J. 2008, 23, 99.

8. Vargas, R. M. F.; Cassel, E.; Gomes, G. M. F.; Longhi, L. G. S.; Atti-Serafini, L.; Atti-Santos, A. C.; Braz. J. Chem. Eng. 2006, 23,375 .

9. Giuliano, D. A.; Darwiniana 2001, 39, 131.

10. Nesom, G.; Robinson, H. In The Families and Genera of Vascular Plants; Kadereit, J. W.; Jeffrey, C., eds.; Springer: Berlin, 2006.

11. Zunino, M. P.; Lopez, M. L.; Zygadlo, J. A.; Lopez, A. G.; J. Essent. Oil Res. 2004, 16, 29.

12. Tonn, C. E.; Gianello, J. C.; Guidugli, F. H.; An. Asoc. Quím. Argent. 1987, 75, 5.

13. Zunino, M. P.; Newton, M. N.; Maestri, D. M.; Zygadlo, J. A.; Planta Med. 1998, 64, 86.

14. Agostini, F.; Santos, A. C. A.; Rossato, M.; Pansera, M. R.; Zattera, F.; Wasum, R.; Serafini, L. A.; Braz. J. Pharmacogn. 2005, 15, 215.

15. Simionatto, E.; Ilha, V.; Mallmann, A. S.; Porto, C.; Dalcol, I. I.; Morel, A. F.; J. Essent. Oil Res. 2008, 20, 366.

16. Simões-Pires, C. A.; Debenedetti, S.; Spegazzini, E.; Mentz, L. A.; Matzenbacher, N. I.; Limberger, R. P.; Henriques, A. T.; Pl. Syst. Evol. 2005, 253, 23.

17. Zunino, M. P.; Novillo-Newton, M.; Maestri, D. M.; Zygadlo, J. A.; Flav. Fragr. J. 1997, 12, 405.

18. Queiroga, C. L.; Fukai, A.; Marsaioli, A. J.; J. Braz. Chem. Soc. 1990, 1, 105.

19. Loayza, I.; Abujder, D.; Aranda, R.; Jakupovic, J.; Collin, G.; Deslauriers, H.; Jean, F.-I.; Phytochemistry 1995, 38, 381.

20. Klopell, F. C.; Lemos, M.; Sousa, J. P. B.; Comunello, E.; Maistro, E. L.; Bastos, J. K.; Andrade, S. F.; J. Biosci. 2007, $62,537$.

21. Naves, Y. R.; Bull. Soc. Chim. Fr. 1959, 1871. 
22. Bauer, L.; Brasil e Silva, G. A. de A.; De Siqueira, N. C. S.; Bacha, C. T. M.; Sant'Ana, B. M. S.; Rev. Cent. Cienc. Saúde 1978, 6, 7 .

23. Chialva, F.; Doglia, G.; J. Essent. Oil Res. 1990, 2, 173.

24. Loayza, I.; Collin, G.; Gagnon, M.; Dellacassa, E.; Rivista Italiana EPPOS 1993, 728.

25. Rojas, J.; Velasco, J.; Rojas, L. B.; Diaz, T.; Carmona, J.; Morales, A.; Nat. Prod. Commun. 2007, 2, 1245.

26. Garcia, M.; Donadel, O. J.; Ardanaz, C. E.; Tonn, C. E.; Sosa, M. E.; Pest Manag. Sci. 2005, 61, 612.

27. Flores, R. C.; Ponzi, M.; Ardanaz, C.; Tonn, C. E.; Donadel, O. J.; J. Chil. Chem. Soc. 2009, 54, 475.

28. Lago, J. H. G.; Romoff, P.; Fávero, O. A.; Souza, F. O.; Soares, M. G.; Baraldi, P. T.; Corrêa, A. G.; Biochem. Syst. Ecol. 2008, 36, 737 .

29. De Ferrante, L. M. S.; Mayer, B.; Vasconcelos, E. C.; de Oliveira, C. M. R.; Braz. J. Pharmacogn. 2007, 17, 356.

30. Frizzo, C. D.; Atti-Serafini, L.; Dellacassa, E.; Lorenzo, D.; Moyna, P.; Flav. Fragr. J. 2001, 16, 286.

31. Lago, J. H. G.; Romoff, P.; Fávero, O. A.; Soares, M. G.; Baraldi, P. T.; Corrêa, A. G.; Souza, F. O.; Quim. Nova 2008, 31, 727.

32. Fabiane, K. C.; Ferronatto, R.; Dos Santos, A. C.; Onofre, S. B.; Braz. J. Pharmacogn. 2008, 18, 197.

33. Ascari, J.; Nunes, D. S.; Marques, M. B.; Tardivo, R. C.; Cechinel-Filho, V.; Simionatto, E. L.; Wisniewski Jr., A.; Publicatio UEPG - Ciências Exatas e da Terra, Agrárias e Engenharias 2009, 15, 73.

34. Rosso, M. L.; Maier, M. S.; Bertoni, M. D.; Molecules 2000 , 5,345 .

35. Fagundes, M.; Neves, F. S.; Fernandes, G. W.; Ecol. Entomol. 2005, 30, 28.

36. Mendes, S.; Nunes, D. S.; Marques, M. B.; Tardivo, R. C.; Cechinel-Filho, V.; Simionatto, E. L.; Wisniewski Jr., A.; Publicatio UEPG - Ciências Exatas e da Terra, Agrárias e Engenharias 2008, 14, 241.
37. Stahl, E.; Schild, W.; Pharmazeutische Biologie. 4. Drogenanalyse II: Inhaltsstoffe und Isolierungen; GustagFischer Verlag: Stuttgart, 1981.

38. Van den Dool, H.; Kratz, P.; J. Chromatogr. 1963, 11, 463.

39. Gemperline, P.; A Pratical Guide to Chemometrics, $2^{\text {nd }}$ ed.; CRC Press: London, 2006.

40. Adams, R. P.; Identification of Essential Oil Components by Gas Chromatography-Mass Spectroscopy; Carol Stream: Allured, 1995.

41. Queiroga, C.; Bastos, J. K.; de Souza, J. P. B.; Magalhães, P. M.; J. Essent. Oil Res. 2007, 20, 111.

42. De Souza, J. P. B.; Jorge, R. F.; Leita, M. F.; Furtado, N. A. J. C.; Bastos, J. K.; Da Silva Filho, A. A.; Queiroga, C. L.; Magalhães, P. M.; Soares, A. E. E.; J. Essent. Oil Res. 2009, 21, 308.

43. Scholander, P. F.; Brastreet, E. D.; Hemmingsen, E. A.; Hammel, H. T.; Science 1965, 148, 3668.

44. Charles, D. J.; Joly, R. J.; Simon, J. E.; Phytochemistry 1990, $29,9$.

45. Bettaieb, I.; Zakhama, N.; Aidi-Wannes, W.; Kchouk, M. E.; Marzouk, B.; Sci. Hortic. 2009, 120, 271.

46. Heiden, G.; Iganci, J. R. V.; Macias, L.; Rodriguésia 2009, 60, 943.

47. Barroso, G. M.; Rodriguésia 1976, 28, 3.

48. Bailac, P. N.; Dellacasa, A. D.; Bernasconi, H. O.; Ponzi, M. I.; Firpo, N. H.; J. Essent. Oil Res. 2001, 13, 23.

Submitted: January 31, 2012

Published online: May 3, 2012

FAPESP has sponsored the publication of this article. 


\title{
Chemical Composition Similarity between the Essential Oils Isolated from Male and Female Specimens of Each Five Baccharis Species
}

\author{
Michele A. Besten, ${ }^{a}$ Vanessa C. G. Jasinski, ${ }^{a}$ Ângela de G. L. C. Costa, ${ }^{a}$ Domingos S. Nunes, $*, a$ \\ Sávio L. Sens, ${ }^{b}$ Alberto Wisniewski Jr., ${ }^{c}$ Edesio L. Simionatto, ${ }^{d}$ Dilamara Riva, ${ }^{d}$ \\ Juliana B. Dalmarco ${ }^{d}$ and Daniel Granato ${ }^{e}$ \\ ${ }^{a}$ Departamento de Química, Universidade Estadual de Ponta Grossa, \\ 84030-900 Ponta Grossa-PR, Brazil \\ ${ }^{b}$ Centro de Educação Tecnológica Irmão Mário Cristóvão (TECPUC), \\ 80215-901 Curitiba-PR, Brazil \\ 'Departamento de Química, Universidade Federal de Sergipe, 49100-000 São Cristóvão-SE, Brazil \\ ${ }^{d}$ Laboratório de Cromatografia, Fundação Universidade Regional de Blumenau, \\ 89030-000 Blumenau-SC, Brazil \\ eInstituto Adolfo Lutz, Centro de Materiais de Referência, \\ Av. Dr. Arnaldo, 355, 01246-000 São Paulo-SP, Brazil
}

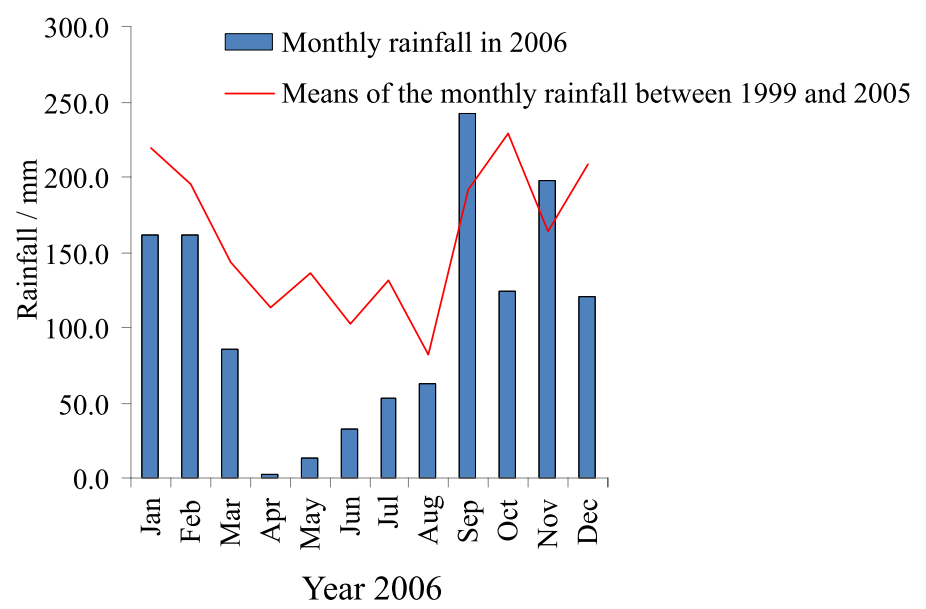

Figure S1. Mean monthly pluviometric precipitation between 1999 and 2005, and mean monthly rainfall during 2006 near the place where the botanical materials were collected. These data were provided by the Meteorological Station of the Farm School from the State University of Ponta Grossa (Paraná State, Brazil), supplement the discussion about the influence of rainfall on the composition of essential oils obtained from female and male specimens, and refer to the case of $B$. dracunculifolia.

*e-mail: dsnunes@pq.cnpq.br 
Table S1. Rainfall data for the months in which the sample collections were made, showing that all collections occurred by dry weather. Plant collections: B. dracunculifolia ${ }^{\mathrm{a}}$ at 2 p.m., B. coridifolia ${ }^{\mathrm{b}}$ at 4 p.m., B. semiserrata var. elaegnoides ${ }^{\mathrm{c}}$ at 5 p.m., B. caprariaefolia $^{\mathrm{d}}$ at 4 p.m. and B. pentaptera $^{\mathrm{e}}$ at 11 a.m. The data below supplement the information given in the Experimental section of the printed version

\begin{tabular}{|c|c|c|c|c|}
\hline \multirow{2}{*}{ Day } & \multicolumn{4}{|c|}{ Rainfall / mm } \\
\hline & August, 2006 & April, 2007 & September, 2007 & February, 2009 \\
\hline 1 & 0 & 0 & 0 & 0 \\
\hline 2 & 0 & 0 & 0 & 0 \\
\hline 3 & 0 & 11 & 13 & 28 \\
\hline 4 & 0 & 0 & 0 & 10 \\
\hline 5 & 0 & 0 & 0 & 0 \\
\hline 6 & 0 & 0 & 0 & 0 \\
\hline 7 & 0 & 0 & 0 & 15 \\
\hline 8 & $0^{\mathrm{a}}$ & 9 & 0 & 70 \\
\hline 9 & 0 & 0 & 0 & 0 \\
\hline 10 & 0 & 0 & 0 & 0 \\
\hline 11 & 0 & 0 & 0 & 9 \\
\hline 12 & 0 & 0 & 0 & $0^{\mathrm{f}}$ \\
\hline 13 & 0 & 0 & 0 & 0 \\
\hline 14 & 0 & 0 & $0^{\mathrm{c}}$ & 0 \\
\hline 15 & 0 & 0 & 0 & 0 \\
\hline 16 & 15 & 0 & 0 & 89 \\
\hline 17 & 10 & 0 & $0^{\mathrm{d}}$ & 0 \\
\hline 18 & 30 & 0 & 0 & 0 \\
\hline 19 & 0 & 0 & 3 & 0 \\
\hline 20 & 0 & $0^{\mathrm{b}}$ & 8 & 0 \\
\hline 21 & 0 & 0 & 0 & 21 \\
\hline 22 & 0 & 0 & 8 & 0 \\
\hline 23 & 0 & 12 & 0 & 0 \\
\hline 24 & 0 & 8 & 0 & 0 \\
\hline 25 & 0 & 8 & 0 & 0 \\
\hline 26 & 8 & 44 & 0 & 17 \\
\hline 27 & 0 & 0 & 0 & 0 \\
\hline 28 & 0 & 0 & 0 & 17 \\
\hline 29 & 0 & 0 & 0 & - \\
\hline 30 & 0 & 0 & 0 & - \\
\hline 31 & 0 & - & - & - \\
\hline
\end{tabular}

Table S2. Data found in the literature that show quantitative differences $(\%)$ in some of the main components of essential oils from female ( $(+)$ and male (ठ) specimens of B. articulata (Bar), B. caprariaefolia (Bca), B. dracunculifolia (Bdr), B. erioclada (Ber), B. semiserrata (Bss) and B. trimera (Btr). ${ }^{1-4}$ This table refers to all information available in the literature and supplements the data discussed in the Introduction

\begin{tabular}{|c|c|c|c|c|c|c|c|c|c|c|c|c|}
\hline Components & Bar? & $\operatorname{Bar}^{\wedge}$ & $\mathrm{Bca}+$ & $\mathrm{Bca}^{\lambda}$ & $\mathrm{Bdr}_{+}+$ & $\operatorname{Bdr} \overbrace{}^{\lambda}$ & Ber + & Ber ${ }^{\lambda}$ & Bss $q$ & $\operatorname{Bss}{ }^{\lambda}$ & Btr $्$ & $\operatorname{Btr}{ }^{\lambda}$ \\
\hline$\alpha$-Pinene & & & & & & & 8.5 & 0.3 & & & 6.1 & 2.1 \\
\hline$\beta$-Pinene & 14.7 & 0.1 & & & & & 21.4 & 1.2 & & & & \\
\hline Limonene & & & & & 4.7 & 0.9 & 15.2 & 2.7 & & & & \\
\hline$\alpha$-Terpineol & & & 0.0 & 5.9 & & & & & & & & \\
\hline Aromadendrene & & & & & & & & & 9.6 & 2.3 & & \\
\hline$\alpha$-Humulene & & & & & & & & & & & 0.0 & 20.3 \\
\hline$\alpha$-Muurolene & & & & & & & & & 8.9 & 2.4 & & \\
\hline Germacrene D & & & & & & & & & & & 0.0 & 12.3 \\
\hline Bicyclogermacrene & & & & & & & & & & & 7.8 & 3.0 \\
\hline Germacrene A & & & & & & & & & & & 0.0 & 7.8 \\
\hline$\delta$-Cadinene & & & & & & & & & 9.5 & 3.9 & & \\
\hline$\alpha$-Cadinene & & & & & & & & & & & 11.6 & 0.0 \\
\hline (E)-Nerolidol & & & 8.9 & 0.4 & 20.8 & 12.0 & & & & & & \\
\hline Spathulenol & & & & & & & 6.6 & 12.6 & & & & \\
\hline$\alpha$-Cadinol & & & & & & & & & & & 8.5 & 0.2 \\
\hline
\end{tabular}


Table S3. Relative composition and distribution of the components that could not be identified in the analyses of the essential oils obtained from leaves of female (ㅇ) and male (ふ) specimens of B. caprariaefolia (Bca), B. dracunculifolia (Bdr), B. semiserrata var. elaegnoides (Bse), B. coridifolia (Bco) and B. pentaptera (Bpe). The data presented here supplement those appearing in the Table 1 for the identified components (main text)

\begin{tabular}{|c|c|c|c|c|c|c|c|c|c|c|c|}
\hline Components & ${ }^{a} \mathrm{RI}$ & $\mathrm{Bca}+$ & $\mathrm{Bca}_{0}^{\pi}$ & $\mathrm{Bdr}+$ & $\operatorname{Bdr} \sigma^{\lambda}$ & Bse + & $\operatorname{Bse}^{\lambda}$ & $\mathrm{Bco}$ 우 & $B \cos$ & $\mathrm{Bpe}+$ & Bpe $\overbrace{}^{\pi}$ \\
\hline $\mathrm{C}_{10} \mathrm{H}_{16} \mathrm{M}^{+}, \mathrm{m} / z 136$ & 1022 & nd & nd & 0.23 & 0.12 & nd & nd & nd & nd & nd & nd \\
\hline $\mathrm{C}_{15} \mathrm{H}_{24} \mathrm{M}^{+}, m / z 204$ & 1360 & nd & nd & 0.76 & 0.99 & nd & nd & nd & nd & nd & nd \\
\hline $\mathrm{C}_{15} \mathrm{H}_{24} \mathrm{M}^{+}, \mathrm{m} / z 204$ & 1392 & nd & nd & nd & nd & nd & nd & nd & nd & 2.31 & 1,99 \\
\hline $\mathrm{C}_{15} \mathrm{H}_{24} \mathrm{M}^{+}, m / z 204$ & 1530 & nd & nd & nd & 0.85 & nd & nd & nd & nd & nd & nd \\
\hline $\mathrm{C}_{15} \mathrm{H}_{24} \mathrm{M}^{+}, \mathrm{m} / \mathrm{z} 204$ & 1541 & nd & nd & nd & nd & nd & nd & nd & nd & 0.74 & 0.62 \\
\hline $\mathrm{C}_{15} \mathrm{H}_{24} \mathrm{O} \mathrm{M}^{+}, \mathrm{m} / \mathrm{z} 220$ & 1586 & 2.74 & 1.45 & 0.23 & 0.43 & 4.68 & 1.05 & nd & nd & nd & nd \\
\hline $\mathrm{C}_{15} \mathrm{H}_{24} \mathrm{O} \mathrm{M}^{+}, m / z 220$ & 1593 & 0.76 & 0.23 & nd & nd & nd & nd & nd & nd & nd & nd \\
\hline $\mathrm{C}_{15} \mathrm{H}_{22} \mathrm{M}^{+-}-18, \mathrm{~m} / \mathrm{z} 204$ & 1606 & nd & nd & nd & nd & nd & nd & 1.32 & 1.09 & nd & nd \\
\hline $\mathrm{C}_{15} \mathrm{H}_{26} \mathrm{OM}^{+}, \mathrm{m} / \mathrm{z}, 222$ & 1610 & nd & nd & nd & nd & nd & nd & nd & nd & 2.18 & 1.26 \\
\hline $\mathrm{C}_{15} \mathrm{H}_{26} \mathrm{O} \mathrm{M}^{+}, \mathrm{m} / z 222$ & 1617 & nd & nd & nd & nd & nd & nd & nd & nd & 6.06 & 3.49 \\
\hline $\mathrm{C}_{15} \mathrm{H}_{22} \mathrm{M}^{+}-18, \mathrm{~m} / \mathrm{z} 204$ & 1622 & nd & nd & nd & nd & nd & nd & 3.21 & 2.79 & nd & nd \\
\hline $\mathrm{C}_{15} \mathrm{H}_{24} \mathrm{O} \mathrm{M}^{+}, m / z 220$ & 1626 & nd & nd & nd & nd & nd & 2.05 & 2.27 & 2.91 & nd & nd \\
\hline $\mathrm{C}_{15} \mathrm{H}_{22} \mathrm{M}^{+-}-18, \mathrm{~m} / \mathrm{z} 204$ & 1636 & 0.41 & 0.64 & nd & nd & nd & nd & nd & nd & nd & nd \\
\hline $\mathrm{C}_{15} \mathrm{H}_{24} \mathrm{O} \mathrm{M}^{+}, m / z 220$ & 1640 & nd & nd & nd & nd & nd & nd & 3.53 & 0.95 & nd & nd \\
\hline $\mathrm{C}_{15} \mathrm{H}_{24} \mathrm{OM}^{+}, m / z, 220$ & 1644 & nd & nd & nd & nd & nd & nd & 4.08 & 1.57 & nd & nd \\
\hline $\mathrm{C}_{15} \mathrm{H}_{23} \mathrm{M}^{+-}-17, \mathrm{~m} / \mathrm{z} 205$ & 1650 & 1.84 & 2.42 & nd & nd & nd & nd & nd & nd & nd & nd \\
\hline $\mathrm{C}_{15} \mathrm{H}_{26} \mathrm{OM}^{+}, \mathrm{m} / z, 222$ & 1668 & nd & nd & nd & nd & 2.99 & nd & nd & nd & nd & nd \\
\hline $\mathrm{C}_{14} \mathrm{H}_{24} \mathrm{O} \mathrm{M}^{+}, m / z, 208$ & 1674 & 0.69 & 0.85 & nd & nd & nd & nd & nd & nd & nd & nd \\
\hline $\mathrm{C}_{15} \mathrm{H}_{26} \mathrm{O} \mathrm{M}^{+}, m / z, 222$ & 1681 & 1.63 & 0.34 & 1.24 & 0.22 & nd & nd & nd & nd & nd & nd \\
\hline $\mathrm{C}_{15} \mathrm{H}_{26} \mathrm{O} \mathrm{M}^{+}, m / z, 222$ & 1683 & 0.7 & 0.47 & nd & nd & nd & nd & nd & nd & nd & nd \\
\hline $\mathrm{C}_{13} \mathrm{H}_{22} \mathrm{O} \mathrm{M}^{+}, m / z 194$ & 1686 & 0.21 & 0.11 & nd & nd & nd & nd & nd & nd & nd & nd \\
\hline $\mathrm{C}_{15} \mathrm{H}_{26} \mathrm{O} \mathrm{M}^{+}, m / z, 222$ & 1690 & 1.97 & 0.76 & nd & nd & nd & nd & nd & nd & 4.47 & 2.88 \\
\hline $\mathrm{C}_{15} \mathrm{H}_{26} \mathrm{O} \mathrm{M}^{+}, m / z, 222$ & 1697 & 0.54 & 0.79 & nd & nd & nd & nd & nd & nd & nd & nd \\
\hline $\mathrm{C}_{15} \mathrm{H}_{22} \mathrm{O} \mathrm{M}^{+}, m / z, 218$ & 1699 & nd & nd & nd & nd & 3.20 & 2.43 & nd & nd & nd & nd \\
\hline $\mathrm{C}_{15} \mathrm{H}_{26} \mathrm{O} \mathrm{M}^{+}, m / z, 220$ & 1703 & nd & 0.82 & nd & nd & nd & nd & nd & nd & nd & nd \\
\hline $\mathrm{C}_{15} \mathrm{H}_{26} \mathrm{O} \mathrm{M}^{+}, m / z, 222$ & 1704 & nd & nd & nd & nd & 0.36 & 0.12 & nd & nd & nd & nd \\
\hline $\mathrm{C}_{15} \mathrm{H}_{26} \mathrm{O} \mathrm{M}^{+}, m / z, 220$ & 1706 & nd & 1.56 & nd & nd & nd & nd & nd & nd & nd & nd \\
\hline $\mathrm{C}_{15} \mathrm{H}_{26} \mathrm{O} \mathrm{M}^{+}, m / z, 222$ & 1708 & nd & nd & nd & nd & 0.96 & 0.77 & nd & nd & nd & nd \\
\hline $\mathrm{C}_{15} \mathrm{H}_{26} \mathrm{O} \mathrm{M}^{+}, m / z, 222$ & 1714 & 1.18 & 2.28 & nd & nd & nd & nd & nd & nd & nd & nd \\
\hline $\mathrm{C}_{15} \mathrm{H}_{22} \mathrm{O} \mathrm{M}^{+}, m / z 218$ & 1726 & nd & nd & nd & 1.20 & nd & 1.03 & nd & nd & nd & nd \\
\hline $\mathrm{C}_{15} \mathrm{H}_{26} \mathrm{O}_{2} \mathrm{M}^{+}, m / z 238$ & 1730 & 0.22 & 0.65 & nd & nd & nd & nd & nd & nd & nd & nd \\
\hline $\mathrm{C}_{15} \mathrm{H}_{22} \mathrm{O} \mathrm{M}^{+}, m / z 218$ & 1732 & nd & nd & nd & 0.35 & nd & nd & nd & nd & nd & nd \\
\hline $\mathrm{C}_{16} \mathrm{H}_{22} \mathrm{O}_{4} \mathrm{M}^{+}, m / z, 278$ & 1760 & nd & nd & nd & nd & nd & 1.75 & nd & nd & nd & nd \\
\hline Total notIdentified ${ }^{\mathrm{b}} / \%$ & & 12.89 & 13.37 & 2.46 & 4.16 & 12.19 & 9.20 & 14.41 & 9.31 & 15.76 & 10.24 \\
\hline
\end{tabular}

aRI: means of calculated relative retention indices using the apolar columns CP-Sil-8 (GC-MS) and OV-5 (GC-FID), and the n-alkane series C10-C30; brelative areas smaller than $0.10 \%$ were not considered in the GC-FID analyses and were taken as "not detected" (nd).

\section{References}

1. Ferracini, V. L.; Paraíba, L. C.; Leitão-Filho, H. F.; Da Silva, A. G.; Nascimento, L. R.; Marsaioli, A. J.; J. Essent. Oil Res. $1995,7,355$.

2. Zunino, M. P.; Lopez, M. L.; Zygadlo, J. A.; Lopez, A. G.; J. Essent. Oil Res. 2004, 16, 29.28.

3. Lago, J. H. G.; Romoff, P.; Fávero, O. A.; Souza, F. O.; Soares, M. G.; Baraldi, P. T.; Corrêa, A. G.; Biochem. Syst. Ecol. $2008,36,737$.

4. Mendes, S.; Nunes, D. S.; Marques, M. B.; Tardivo, R. C.; Cechinel-Filho, V.; Simionatto, E. L.; Wisniewski Jr., A.; Publicatio UEPG -

Ciências Exatas e da Terra, Agrárias e Engenharias 2008, 14, 241. 